\title{
PATHO-ANATOMY OF ROOTS ATTACKED BY NEIMATODES
}

\author{
By Melville T. Cook, Plant Pathologist, \\ Insular Experiment Station, Río Piedras, P. R.
}

Very little study has been made in America of the anatomy of plants attacked by nematodes since the publication of Atkinson's "Nematode Root-Galls" (1) in 1889. During the past few years the writer has devoted some attention to this subject and the data on the dicotyledonous plants will be presented in this paper. The plants used in these studies were tomato, tobaceo and ornamental Coleus. The results were the same in all cases and it would have been impossible to distinguish them except for the labels. The galls were caused by Heterodera marioni (Cornu) Goodey (= Heterodera radicicola Greeff).

The nematodes attack the very young roots. The writer is of the opinion that they rarely, if ever, attack roots more than one millimeter in diameter. Young roots contain a large amount of tissue that is capable of division when stimulated. This includes the cambium, cortex and medullary rays. The parasites penetrate into the cortex and the rays where they stimulate an excessive growth. The writer is of the opinion that they rarely if ever penetrate into the fibrous or tracheary tissue.

All cells that retain the power of division are stimulated by the parasites. This stimulation results in the formation of a large number of very small cells in close contact with the parasite while those a-distance are much larger (Figs. $3 \& 5 \mathrm{~b}$ ). When the nematode attains full size the stimulation appears to cease and the cells become larger (Fig. 4b). The parasite does not appear to stimulate cell division or growth in the fibrous or tracheary tissues, but does push them out of the normal position. The parasite also causes the formation of tracheary tissues from and in the parenchyma tissue (Fig. 1b.)

Nematodes in the axis cylinder (Fig. 2) penetrated through the parenchyma cells and not through the fibrous or tracheary cells.

The writer is inclined to believe that galls may be reinfected many times and that reinfection accounts for the larger galls. The tissues of a gall are highly meristematic as a result of stimulation by previous infections and are very favorable for reinfections. The tissues of the large galls are in such a state of confusion resulting from the large number of parasites and the reinfections that a histological 
study is of little or no value. Any satisfactory study of the development of these galls should begin with the very young galls.

Atkinson's studies evidently were made on the galls that were advanced to a point where it was impossible to determine the incipient characters, but his description and discussion are very interesting. He said:

"The worms locate preparatory to passing into the cystic state at various depths in the tissues of the root. They are not confined to any particular tissue element or system but locate in the vascular tissue of the central cylinder, the cambium, parenchyma or even in the bark so that the body of the mature female cyst is frequently only protected by a thin layer of the dead peripheral tissue, or sometimes is evell exposed. They seem to flourish better, however in or near the softer tissues of the root. It is a very common thing to find dead undeveloped female eysts, the majority of which $I$ lave always found in the woody tissue of the central cylinder. Possibly surrounded as they are by the harder, more compact tissue there is less certainty of the male reaching them for fertilization. This, however, is only a suggestion. I have not demonstrated it. All of the tissue elements in the diseased roots undergo hypertrophy, while some of them are subject to special changes in form as well as direction of growth.

"The parenchyma cells which normally have their tangential diameter greater than the radial are so changed that the radial diameter is the greater. This change in form of the parenchyma cells seems to obtain in nearly all of the parenchyma in the gall whether very near a cyst or distant from it. The increase in number of the wood and vascular cells of the central cylinder takes place though the cyst may not be located in or very near it. In such cases the fibres and ducts have their normal longitudinal direction. But if a cyst is located in or very near the central eylinder the ducts are turned in their direction of growth perpendicular to the axis of the root, bent around the eyst and then converge on the peripheral side, when, left, without any controlling influenee over their direction of growth they often perform very curious evolutions through the parenchymatous tissue in all directions."

My results are not altogether in harmony with those given by Atkinson. Some of the nematodes stop in the cortex of the roots while others penetrate to the center of the axis cylinder which makes it necessary to consider the action of the nematodes on these two sets of tissues.

The writer agrees with Atkinson in the statement that the nematodes are found in all the tissues of the galls but as a result of studies on very young galls, the writer is of the opinion that the galls originate in the very young roots and at a period when most of the cells have retained the power of division. The writer is very doubtful if the parasites ever penetrate into the fibrous and tracheary tissues. The galls appear to originate in the young cortical tissues. As a result of the irritation by the parasites the fibrous and tracheary 
tissues in the axis cylinder become distorted and sometimes displaced; new fibrous and tracheary tissues are formed in the cortical regions.

The size and shape of the galls depends primarily on the number of parasites in the roots and to some extent on their position in the roots and the age of the roots at time of infection. The writer is of the opinion that roots of more than one millimeter are rarely if ever infested.

The writer disagrees with Atkinson in his statement that "all the tissue elements in the diseased roots undergo hypertrophy". There is no hypertrophy of the tracheary tissue but new tracheary tissue is formed from the cortex. The writer also disagrees with Atkinson's statement that "the parenchyma cells which normally have their tangential diameter greater than the radial are so changed that the radial diameter is the greater". This statement is sometimes true especially in the very large galls which contain a large number of the parasites.

There is an enlargement of the roots due primarily to the excessive division and growth of the cells of the cortex. In most cases these cells are only slightly modified. Those next to the nematodes are somewhat smaller than normal. The larger cells may be slightly shorter (i. e. isodiametric) than in normal roots.

The cells in the axis cylinder do not increase in number but are pushed out of place by the growing nematodes.

There is a tendency for an increase in the amount of tracheary cells at the expense of the fibrous cells. Sometimes the axis cylinder is supplanted by the nematodes.

One part of an axis cylinder may be distorted and the other part normal.

The final result of the stimulation by the parasite is great masses of cells, the formation of new fibrous and tracheary tissues which are intermingled in the parenchyma in an irregular manner.

Atkinson compared the nematode galls with those caused by Plasmodiophora brassicae as follows:

"But if we take a thin transwerse section of an enlarged root of each and compare them all resemblance vanishes. In a eross section of 'club-foot' the first thing to attract attention is the great number of yellowish plasmodia, or else the spore masses within large eells, distributed all through the tissues. If the section is from an enlargement of a lateral root, unless very large, there will be little else to attract the attention when compared with a healthy root unless it be a slight enlargement of some of the other cells. The general char- 
acter of the root structure is but little changed. The tracheral tissue of the axis eylinder, but little attacked is arranged in the same stellate form which we find it in a healthy root. The ducts, even when immediately in contact with cells containing plasmodia, are not turned from their longitudinal direction, or if so only slightly. The cells are not elongated and curved around the enlarged cells containing the plasmodium, but resemble the normal arrangement of small cells around a large one. Nor is the radial diameter of the parenchymatous cells proportionately increased, but if the cells are enlarged it is usually a proportionate or nearly symetrical enlargement.",

The above comparison is very satisfactory for a comparison of sections of galls well advanced in their development. However, comparisons of the old galls are of very little value: Comparisons of young galls would no doubt give us some information concerning the developmental history. The writer has not had an opportunity of studying the Plasmodiophora brassicae galls but judging from the description of the histology by Lutman (2) and Kunkel, (4) they are much more simple in structure than the galls caused by nematodes. Lutman said:

"The difference between the cross-sections from a healthy root and those from a diseased one lies in the presence in the greatly hypertrophied cells of the cortical parenchyma of an opaque, colorless, finely granular plasma. The cortex is greatly increased in size and this enlargement is due to an increase in the number of the cells as well as to hypertrophy of the individuals. The vessels are often bent and shoved out of their proper position in diseased roots, but, as in normal ones, only contain air. The hypertrophied cells become filled in the older roots with small round spores of the organism to which Woronin gave the name of Plasmodiophora Brassicae.

Kunkel does not give us the history of the development of the very young galls caused by $P$. brassicae, but he said:

"Many of the host cells are very much enlarged, especially near the point of original infection. During the sixteenth and seventeenth days the parasite spreads still farther into the healthy tissues of the stem. It has not penetrated very much deeper, however, and does not seem to be able to attack the woody parts, at least to any very considerably extent.

"While the thickening of the cortex is accomplished more by cell growth than by cell multiplication, the swelling in the cambium region is brought about largely by an increase in the number of cells."

He also stated that the cambium contributed to the enlargement, that the cortex grew, that the cortical cells were enlarged while those of the cambial region were small and that the parasite penetrated the rays and stimulated the cells so that the bundles were forced apart.

It appears to the writer that the galls resulting from nematodes are much more complex than the galls caused by $P$. brassicae. 

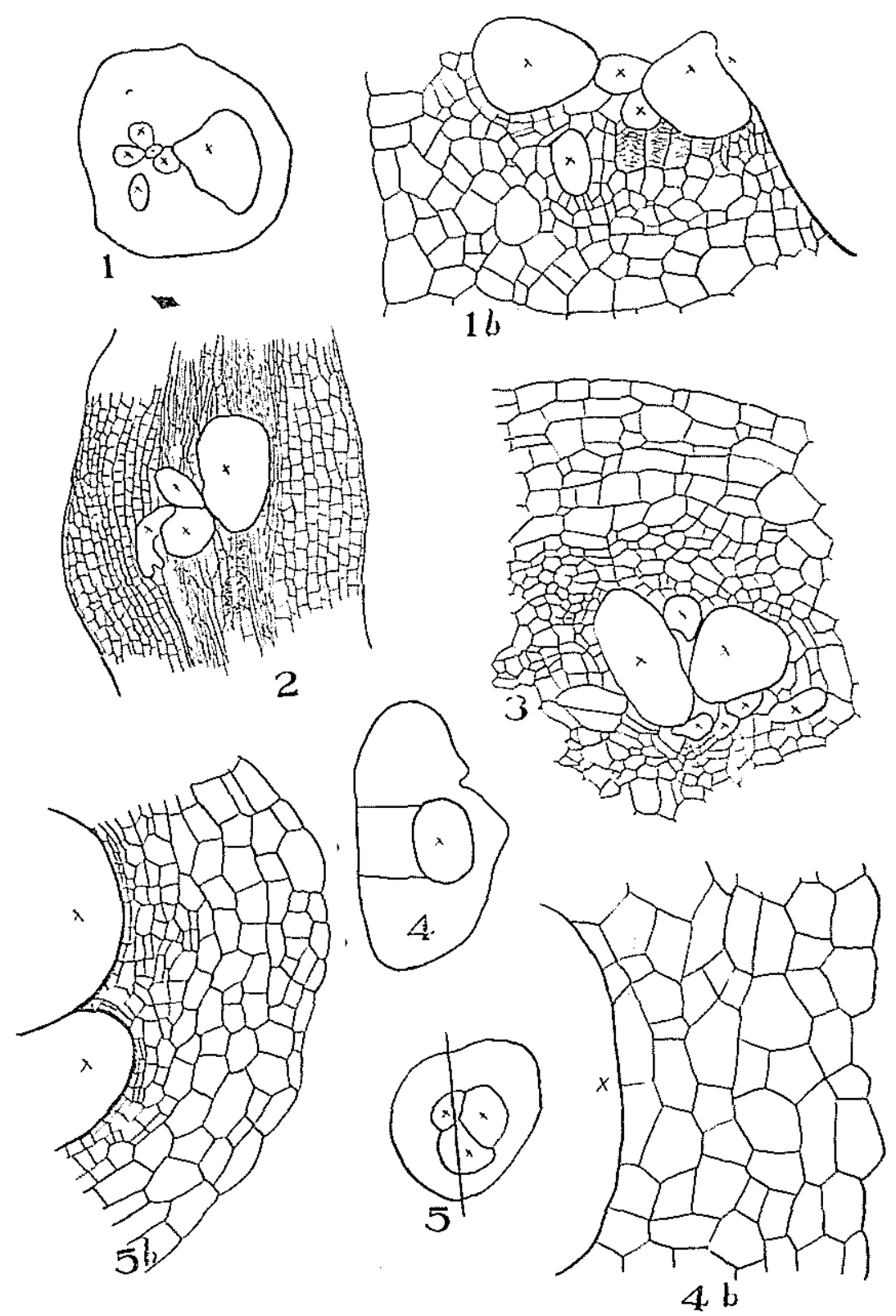


\section{SUMMARY}

1. Root galls caused by nematodes (Heterodera marioni) originate as a result of attacks on meristematic tissues of very young roots.

2. The parasite may locate in the cambium or cortex or penetrate in the medullary rays.

3. There is no evidence that the parasite can attack fully formed fibrous and tracheary tissues or that it can stimulate their growth, but it can push them out of place.

4. The cambium, cortex and medullary rays are stimulated to excessive cell division and tracheary tissue is formed in the cortex.

5 . The cells next to the parasites during the period of gall formation are very small as a result of excessive cell division while the more remote cells are much larger.

\section{LITERATURE}

1. Atkinson, Geo. F. Nematode Galls. Alabaima Agri. Exp. Station. Bulletin No. 9. 1889.

2. Lutman, B. F. Studies on Club-Root. Vermont Agricultural Experiment Station. Bulletin No. 175. 1913.

3. Chupp, Charles. Studies on Club-Root of Cruciferous Plants. New York (Cornell) Agri. Exp. Station. Bulletin 387. 1917. 4. Kunkel, L. O. Tissue Invasion by Plasmodiophora brassicae. Journ. Agri. Research 14:543-575. 1918.

\section{Explanation of Plate}

FIG. 1. Cross section of small root showing location of nematodes. Frg. $1 b$. Part of same showing the effect on the cells.

FIG. 2. Longitudinal section of small root showing location of nematodes.

FIG. 3. Cross section of a root showing location of nematodes. Note there is no tracheary tissue.

Fig. 4. Cross section of a root. Note there is no tracheary tissue.

Fig. $4 b$. Part of same. Note the enlarged parenchyma cells.

FIG. 5. Cross section of small root. Note there is no tracheary tissue.

Fig. $5 b$. Part of same. Note the parenchyma cells. 